\title{
Inovação ou Novidade? Práticas Educativas e Tecnologias Digitais de Rede
}

\author{
Amanda Maciel de Quadros, PPGEDU - UFRGS, \\ amandadequadros@gmail.com \\ Tania Beatriz Iwaszko Marques, PPGEDU - UFRGS, \\ taniabimarques@bol.com.br
}

\begin{abstract}
Resumo. O presente artigo é resultado de uma pesquisa de Mestrado em Educação que analisou a prática pedagógica de professoras que foram alunas de um curso de Pedagogia na modalidade a distância. O curso oportunizou a inclusão digital de suas alunas-professoras e, por isso, acredita-se que possam ter maior propriedade para fazer uso das tecnologias de modo inovador. Inovação Pedagógica é um novo conceito que se insere em uma perspectiva paradigmática emergente, aonde as ações conjuntas da escola e dos professores se dão, através da ruptura com uma situação vigente. A pergunta da pesquisa é 'De que forma professoras, que realizaram a formação num curso a distância mediado por tecnologias digitais de rede, utilizam-nas em sua prática educativa?’. O percurso metodológico foi realizado através de estudo de casos por meio de observações das práticas educativas de três alunas-professoras.
\end{abstract}

Palavras-chave: Inovação Pedagógica; Prática Educativa; Tecnologia Digital de Rede.

\section{Pedagogical Practices and Network Digital Technology: News or Innovation?}

Abstract. This article is the result of research Master of Education analyses that analyzed pedagogical practices of teachers who were students of a Faculty of Education in distance mode. The course propitiates digital inclusion of these students-teachers and, therefore, it is believed that they could have more property to make use of technologies in innovative ways. Pedagogical Innovation is a new concept that fits into a emerging paradigm perspective, where the joint actions of school and teachers are given with a break through the status quo. The question of this research is 'How do teachers, who underwent training in a distance course mediated by network digital technology, use them in their educational practice?'. The methodological approach was performed through case studies through observations with three students-teachers.

Keywords: Pedagogical Innovation; Educational Practice; Network Digital Technology. 


\section{Introdução}

A discussão apresentada é resultado de um estudo realizado durante uma pesquisa de Mestrado acerca da importância e necessidade de discussão na contemporaneidade sobre a inovação pedagógica na prática educativa. As tecnologias proporcionaram transformações presentes em nossos cotidianos, assim como a necessidade de mudança nas escolas. A comunidade escolar busca novos conhecimentos e agrega novas competências às suas práticas, que são essenciais para o uso das tecnologias e readaptação da metodologia aplicada em sala de aula.

Os primeiros olhares sobre esta pesquisa começaram a ser definidos durante nossa experiência e atuação no curso de Pedagogia a Distância (PEAD) da Universidade Federal do Rio Grande do Sul. Essa experiência possibilitou a vivência de uma prática com caráter diferenciado, visto que o curso propunha romper com a organização curricular, através de uma proposta interdisciplinar em cada semestre, por meio dos eixos articuladores. O Seminário Integrador foi uma disciplina proposta em todos os semestres e que visava a acompanhar as alunas-professoras1 em sua trajetória, além do uso das Tecnologias Digitais de Rede (TDR)2, como uma 'Arquitetura Pedagógica'.

O curso nos despertou o interesse em pesquisar a importância das tecnologias na educação em uma perspectiva de trabalho artesanal. Esta perspectiva geralmente é possibilitada, em grande escala, na educação a distância. Sendo assim, foram selecionadas três alunas-professoras do curso PEAD para serem objetos desta pesquisa.

O que se percebe nos tempos atuais é que os espaços escolares estão repletos de alunos ‘famintos' para usarem as tecnologias, e o que se encontra são salas de aulas com muitas novidades (criação de laboratórios de informática, distribuição de computadores e tablets, inserção de projetores multimídias e telas interativas, celulares com conexão wifi) e poucas intervenções dos professores alicerçadas nas tecnologias, contemplando uma proposta inovadora no espaço escolar na sua prática educativa.

Ambos os lados motivaram a construção deste estudo, por compreender a importância da qualificação dos professores e da necessidade deles se aproximarem da realidade em que crianças e jovens estão imersos. Para isso, parte-se do pressuposto que o PEAD incluiu digitalmente suas alunas-professoras e elas têm maior propriedade para fazer o uso das tecnologias de maneira inovadora.

A inserção dessas alunas-professoras egressas do PEAD e da realidade educacional que todos estão vivendo é definida por Castells (2001) como a 'Era Informacional' 3 , que provém de um novo paradigma, alterando as dimensões de tempo e espaço. Acredita-se que esse momento deve ser visto não apenas quando se pensa em 'diversão', mas também no que se refere a novas formas de ensinar e processos de aprender. Essa conjuntura está diretamente relacionada às demandas de inovação nas práticas educativas dos professores em que a sociedade se conecta, relaciona-se e interage em rede.

Nas redes4 estão disponíveis muitas informações, ferramentas, aplicativos e possibilidades multimídias. A tecnologia sozinha não traz contribuições para a educação e, sim, o uso que é feito dela, e, sobre isso, Castells (2001) afirma que "As pessoas moldam a tecnologia para adaptá-la às suas necessidades” (p.386). Esse pressuposto remete à importância do professor conhecer a tecnologia para que junto a sua escola consiga adaptá-las às suas práticas educativas a fim de torná-las inovadoras.

Inseridos neste contexto, diversos cursos de formação de professores estão sendo ofertados, mas ainda percebe-se pouca inovação nas práticas educativas. Ou seja, muitas vezes as novidades estão presentes na escola, mas a prática não é nova. Para Fullan 
(2009, p.20), "no processo de analisar ambientes individuais e coletivos é necessário entender 'o quê' da mudança e o ‘como' da mudança”, para que, além da tecnologia, mude-se, principalmente, a metodologia do trabalho empregado no processo de inovação.

Quando se fala em inovação, refere-se a algo absolutamente inédito e que vem carregado de significações para dar um sentido novo a um determinado contexto. Está implícita em seu significado a quebra de paradigmas e a originalidade na criação de um novo cenário para se fazer algo de maneira intencional. Giget (2008), Fundador do Instituto Europeu de Estratégias Criativas e de Inovação5, descreve que a inovação tem um caráter expressivo por não ser algo copiado de ninguém e por não ter um modelo de referência em sua criação. Isso justifica a diferenciação do seu significado para o conceito de novidades, que está ligado à cópia ou à readaptação de algo já existente.

A novidade perde o seu status rapidamente, pelo fácil acesso de mudança e renovação. Ela está relacionada, muitas vezes, aos modismos que surgem na era informacional. Para Fullan (2009), “[...] é possível mudar 'na superfície’, endossando certos objetivos, usando materiais específicos e até imitando o comportamento sem entender especificamente os princípios e a base racional para a mudança” (p.42). Isso posto, a partir do problema de pesquisa e sob um olhar aguçado, se quer descobrir: 'De que forma professoras, que realizaram a formação num curso a distância mediado6 por tecnologias digitais de rede, utilizam-nas em sua prática educativa?’. Espera-se que este estudo contribua com a discussão das práticas educativas e abordagens de ensino que os professores vêm realizando em suas salas de aulas quando utilizam as TDR.

Os sujeitos da pesquisa são alunas formadas pela Pedagogia a Distância da UFRGS que, ao longo do curso, foram se apropriando das TDR devido às necessidades que o próprio curso apresentava. Essas alunas passaram por um processo de imersão através das tecnologias, buscando suprir suas necessidades de comunicação e acesso à informação. Acredita-se, portanto, que esse processo de formação específico possibilite maior perícia na criação de inovação dessas professoras em suas práticas educativas atuais.

Para melhor articular este estudo, busca-se, como objetivo principal, investigar se o modo como as alunas-professoras egressas da Pedagogia a distância da Universidade Federal do Rio Grande do Sul estão utilizando as tecnologias digitais de rede caracteriza-se como inovação pedagógica em suas práticas educativas. São objetivos específicos: Analisar se as práticas educativas das alunas-professoras egressas do PEAD são inovadoras; Identificar se as tecnologias digitais de rede qualificam as práticas educativas das alunas-professoras egressas do PEAD; Verificar se existem outros fatores intervenientes na comunidade escolar, que fomentem ou dificultem a implementação de práticas educativas inovadoras na escola. Portanto, busca-se contribuir com um olhar sensível e fundamentado sobre a prática educativa que vem sendo realizada na escola das alunas-professoras.

\section{Fundamentos Teóricos}

Para iniciar esta discussão, foi preciso primeiramente analisar o contexto em que a escola se encontra e identificar o novo perfil do aluno imerso nas escolas. A seguir farse-á um apanhado teórico das questões que irão fundamentar o estudo.

A escola ainda apresenta muitas influências do paradigma tradicional/dominante. Entre essas influências pode-se destacar a priorização do conteúdo e da avaliação como processo e produto. Na perspectiva desse paradigma, o modelo ideal de boa conduta na escola é um aluno sem liberdade de expressão, ou seja, um mero receptor de 
informações. Moraes (1996) ainda enfatiza que a escola continua "produzindo seres subservientes, obedientes, castrados em sua capacidade criativa, destituídos de outras formas de expressão e solidariedade" (p.59). Nesse paradigma, ensinar e aprender se resume ao processo de transmissão linear do conhecimento, no qual se trabalha com memorização, repetição e cópia do conteúdo, ou seja, o professor continua sendo o detentor do saber e o aluno o receptor.

Para Moraes (1996), o paradigma tradicional traz "o prevalecimento de um sistema paternalista, hierárquico, autoritário, dogmático [...]. Uma escola que continua dividindo o conhecimento em assuntos, especialidades, subespecialidades, centradas no professor” (p.59). Essa crítica também é feita por Paulo Freire (2009), que defende que, para o aluno construir o seu conhecimento, é preciso dar liberdade e autonomia para que ele mesmo faça suas descobertas e o professor não deve repassar conceitos prontos. Com esse olhar é preciso que o professor esteja a serviço da libertação do seu aluno.

Durante esta pesquisa percebeu-se que o paradigma tradicional ainda está muito presente nas salas de aulas, pois as classes dos alunos se colocam uma atrás da outra, onde o professor fica a frente escrevendo a matéria no quadro ou até mesmo realizando suas avaliações, unicamente, através de provas escritas devido a regras ainda impostas pelo sistema escolar.

Ao contextualizar essa reflexão da metodologia tradicional através da educação formal na educação, Veen e Vrakking (2009) afirmam que se busca um novo saber sobre o velho conhecimento para encontrar alternativas à inserção tecnológica. A ruptura entre os paradigmas se dá, conforme afirmam os autores, através da migração do mundo analógico para o digital, o que exige da sociedade novas estratégias para lidar com a informação.

Com tantas mudanças na maneira de agir e pensar da sociedade, as TDR difundiram-se e foram sendo apresentadas, com o intuito de tornar a informação mais veloz, além de baixar os custos das grandes empresas. Elas surgem através de dispositivos como laptop, netbook, notebook, desktop, tablet, celulares entre outros, para facilitar a comunicação e as trocas de informação da sociedade. Nas escolas nas quais foi realizada a coleta de dados, observou-se o uso do laboratório de informática, celular, máquina fotográfica e notebook por parte das alunas-professoras, sendo que, na maioria das vezes, elas trazem os seus equipamentos pessoais para realizar as atividades com os alunos.

Em geral, as TDR propiciaram que modelos e métodos surgissem perante a uma nova estrutura social, que Castells (2001) denomina como o 'informacionalismo'. Este é um novo modo de desenvolvimento econômico embasado na reestruturação e rejuvenescimento do capitalismo do final do século XX, que visa à expansão tecnológica através do acúmulo de conhecimento e maiores níveis de complexidade no processamento de informações.

Este novo modo de desenvolvimento surge após 1970, seguido do período pósindustrial e se caracteriza pela velocidade das informações rápidas em rede. Segundo Veen e Vrakking (2009, p.29), três aparelhos tiveram um importante papel na vida atual, especialmente na de crianças e jovens. O primeiro foi o controle remoto que permitiu que eles crescessem habituados a trocar os canais da televisão entre uma imensidão de possibilidades, aprendendo, antes mesmo de ler e escrever, a interpretar imagens. Foi aí que surgiu o termo 'zapeando' entre canais. O segundo aparelho é o mouse do computador, dispositivo que possibilitou a navegação pela internet através de ícones e sons, mais do que propriamente pela escrita. O mouse é a 'porta de entrada' para o mundo, aonde o acesso à informação é infinito. E o terceiro, o telefone celular, eliminou a distância física e conectou as pessoas sem restrições, facilitando a 
comunicação entre os pares. E, atualmente, as TDR vêm possibilitando o acesso facilitado à rede através de dispositivos portáteis com acesso à internet e também através da TV digital, que ainda é muito recente.

Tais tecnologias influenciaram o comportamento e o modo de pensar das crianças e jovens que já incorporaram ritmos de vida de acordo com as necessidades da sociedade informacional, através de novos estímulos que se expõem em qualquer local em que estejam imersos, dentro ou fora das salas de aulas. Isto foi identificado durante a coleta de dados da pesquisa, pois os alunos, em sua maioria, demonstravam empolgação ao trabalharem com tecnologias e até relatavam TDR que eles utilizavam em casa, sugerindo jogos e atividades online para os colegas e professores.

Este novo comportamento dos alunos e a inserção das TDR provocam transformações que vêm proporcionando evoluções significativas no espaço escolar, através de mudanças no cotidiano das pessoas, principalmente pela expansão da internet, o que facilitou a comunicação em diferentes meios de comunicação e alterou profundamente as relações interpessoais.

No que se referem às inovações tecnológicas, as TDR são conceituações recentes, diferentes das demais comumente utilizadas e não se encontram muitas referências a respeito, assim como Tecnologias da Informação e Comunicação (TIC) e Novas Tecnologias da Informação e Comunicação (NTIC). Para Teixeira (2005), as terminologias TIC/NTIC estão 'banalizadas' e repetidamente sendo utilizadas para referir-se à distribuição e reprodução de informações. Para Mallagi (2009), quando utilizadas "a dimensão de comunicação no sentido de troca, de processos interativos e colaborativos, como resultado da aplicação da lógica das redes e do hipertexto a estas tecnologias, fica em um segundo plano” (p.108). Isso faz com que o conceito de TDR seja, neste caso, mais adequado para se discutir as inovações pedagógicas, avaliando as práticas educativas através das suas ferramentas.

Assim, percebe-se que o ensino centrado no professor não atende mais as demandas de sujeitos que são proativos e familiarizados com as tecnologias interativas, ou seja, sujeitos que têm iniciativa, que buscam soluções para resolver situações específicas, que pensam adiante e que têm raciocínio rápido. Segundo Veen e Vrakking (2009), “o que pode ser visto na educação é uma luta; uma luta para encaixar a nova tecnologia em um velho modelo; uma luta até mesmo para servir às demandas de mudança da sociedade no modelo existente” (p.90). Os autores defendem que, embora existam professores que ministrem aulas enriquecedoras, as práticas educativas estão ficando defasadas perante as demandas da sociedade informacional.

Apesar do despreparo de grande parte das escolas, nos últimos anos vem se debatendo muito sobre terminologias que definam o perfil do novo aluno que se coloca dentro do espaço social existente. Marc Prensky (2001) criou o termo 'nativo digital' para definir a geração de crianças e jovens que nasceram a partir da década de oitenta, especialmente aqueles nascidos no século XXI. Veen e Vrakking (2009) citam alguns apelidos atribuídos para essa geração conectada, como 'geração da rede', 'geração digital', 'geração internet', 'geração instantânea', 'geração cyber', mas adotam a terminologia de 'homo zappiens', ou seja, “uma nova espécie que atua em uma cultura cibernética global com base na multimídia” (p.30). Também afirmam que, para esta geração, a escola é apenas um (e não o mais importante) dos seus pontos de interesse. Há também os termos trazidos por Tapscott (1999), como a 'Geração Net' e Millenials por Howe e Strauss (2000).

Atualmente, estas têm sido formas expressivas de denominar crianças e jovens que nasceram imersos no mundo da tecnologia. O toque na tela (touchscreen), a ação e reação de algum objeto ao aperto de um botão, o raciocínio não-linear, a busca/pesquisa 
na internet e a habilidade para assumir multitarefas, simultaneamente, são alguns exemplos dos novos hábitos que definem essa nova geração.

Para Prensky (2001), o modelo de pensamento dos alunos imersos nas escolas atualmente é bem diferenciado, devido ao contato direto e intenso com as TDR: "Agora fica claro que como resultado deste ambiente onipresente e o grande volume de interação com a tecnologia, os alunos de hoje pensam e processam as informações bem diferentes das gerações anteriores" (p.1). Essas mudanças exigem que o professor assuma uma postura diferenciada perante os seus alunos e as tecnologias.

Ao encontro da teoria dos autores percebeu-se durante a pesquisa que as alunasprofessoras ainda têm dificuldade de confiar as tecnologias ao manuseio dos alunos. $\mathrm{O}$ fato de elas trazerem as suas TDR pessoais também inviabiliza o uso pelos alunos devido a não ter aparelhos suficientes. Os laboratórios de informática da escola de duas delas está inativo devido à falta de manutenção dos equipamentos e de internet.

As terminologias que definem as gerações digitais já são muito criticadas, e, embora se perceba resistência de uns professores para trabalhar com as tecnologias, outros já estão totalmente imersos no mundo tecnológico. Assim como existem alunos que não apresentam tantas habilidades com as tecnologias. Devido a isso, acredita-se que exista maior facilidade para trabalhar com tecnologias quando se nasce imerso nesse mundo, mas também se reconhece a existência de inúmeras variações nos níveis de experiência de alunos e professores com as tecnologias, o que invalidaria a adoção de um único termo para definir esta ou aquela geração.

Em um artigo mais recente, publicado por Prensky (2009), ele reconhece que, com o passar do tempo, quando todos tiverem crescido na 'Era Digital', tais diferenciações irão se tornar menos relevantes. Nesse segundo momento de sua teoria, o autor traz o conceito de 'sabedoria digital' e salienta que a tecnologia digital serve para nos tornar mais sábios. Para o autor, este conceito tem sentido duplo "[...] referindo-se tanto à sabedoria que vem do uso da tecnologia digital para acessar poderes cognitivos que vão além de nossa capacidade, quanto à sabedoria do uso prudente da tecnologia para melhorar nossas capacidades" (p.1, tradução livre)7. Nessa transição da teoria de Prensky, ele destaca que parte dos professores já exibe uma sabedoria digital, mas que ainda precisam adaptar novas metodologias para suas práticas. A resistência docente presente nas metodologias tradicionais torna a escola monótona, autoritária e linear, onde o acesso às TDR é restrito, enquanto as novas metodologias devem auxiliar a estimular o aluno com questionamentos, instigações e também pela busca de informações através da pesquisa. Desse modo, percebe-se que a prática educativa das alunas-professoras em suas escolas busca mudar suas práticas com o auxílio das tecnologias, mas essa mudança ainda não é suficiente para que elas consigam alterar 0 paradigma e inovem seus fazeres pedagógicos.

A combinação das tecnologias com o avanço da internet vem introduzindo a inserção de inúmeras possibilidades para inovar e tornar a prática educativa mais atraente para o aluno. As salas de aulas virtuais são possibilidades que estão servindo para apoiar o aprendizado do aluno em cursos presenciais e a distância. Estas salas permitem a expansão de conhecimentos através da rede, sem barreiras geográficas, tanto no espaço quanto no tempo, possibilitando o compartilhamento de informações. tecnologias:

Para Campos (2003), um novo cenário se apresenta na escola a partir do uso das

Este novo cenário tecnológico, econômico, social e cultural torna-se a cada dia mais familiar a todos. Mas a escola apresenta uma tendência histórica de retardar a incorporação de inovações em suas práticas pedagógicas. Os produtos do avanço 
tecnológico têm sido absorvidos, usados e dominados primeiramente nos setores mais modernos da sociedade, depois em casa e, por último, na escola (p.9).

Deste modo, percebe-se que as tecnologias vêm proporcionando o rejuvenescimento do espaço escolar, introduzindo salas de informática e atualmente tablets nas salas de aulas. Porém, quando se trabalha com tecnologias, aborda-se uma temática que estará em constante evolução e, provavelmente, quando se fala em atual, este já não seja mais tão atual, visto que as tecnologias estão constantemente evoluindo, a fim de facilitar o seu sistema e abranger cada vez mais possibilidades.

Assim, acredita-se que as TDR apresentam muitos benefícios quando inseridas na escola devido à facilidade de acesso e difusão das informações, mas também há dificuldades como em casos de falta de energia elétrica e de conexão com a internet, além de outros fatores que dificultam o trabalho com as tecnologias.

As TDR contribuem com a interação social, com acesso à informação e estimulam as trocas com sujeitos internos e externos à escola. Nos tempos atuais, nenhuma biblioteca, escola ou professor sozinho consegue abarcar a imensidão de informações que se obtém através das TDR. Para Fino (2008, p.3):

Hoje, como sempre, apesar deste modelo de escola que nos acompanha desde os inícios do século XIX e está à beira de esgotar o prazo de validade, o mundo é o locus da informação, e a vida, incluindo obrigatoriamente a interacção social, é um projecto de adaptação permanente8.

Ao abrir as portas para a inserção de novas práticas educativas, a escola possibilita a imersão no campo da inovação e do rejuvenescimento desse modelo de escola citado pelo autor. Veen e Vrakking (2009, p.56), assim como Fino (2008), enfatizam: "Um dos maiores benefícios da tecnologia foi o de que a informação não é mais uma mercadoria rara. Está disponível para quase todas as pessoas em qualquer lugar do mundo e, mais importante, ao mesmo tempo”. Estas são algumas das possibilidades do uso das tecnologias nos espaços escolares.

Acredita-se que, ao incluir novos subsídios à sala de aula, através de novas práticas educativas, o professor pode estimular o desenvolvimento cognitivo do aluno, potencializando características importantes como a autonomia, a criatividade, a criticidade, a motivação na escola, a busca/pesquisa através de diversas fontes de informação e o desafio, tornando a aprendizagem desejada e lúdica.

O importante é que haja discussões no âmbito educacional para que os professores, junto às suas escolas, valorizem o processo de inovação das práticas educativas. Cada um deve fazer a sua parte, a escola ao investir na formação dos seus professores e na aquisição de tecnologias e os professores através da busca/pesquisa a partir das suas motivações pessoais e individuais. Pois nada adianta salas tecnológicas e professores desatualizados já que "A simples modernização da escola nada tem a ver com a inovação” (SEBARROJA, 2001, p.17). Ela necessita de subsídios que auxiliem de fato a mudar as concepções de ensino e de aprendizagem a partir das práticas dos professores, mudança de hábitos, salas tecnológicas, aulas diferenciadas, pois "muitas vezes mudam-se apenas os nomes das coisas e deixa-se todo o resto exatamente igual” (SEBARROJA, 2001, p.17). Durante a coleta de dados, foram observadas professoras com vontade de implementar novas perspectivas educacionais em escolas que ainda não estão preparadas para tantas mudanças. Esse novo olhar que surge na equipe docente a partir de cursos de capacitação é essencial para que escola e outros professores passem a acreditar em novas perspectivas de trabalho. 
É preciso ter claro que a tecnologia sozinha não educa, não estabelece vínculos, não propicia interação, pois, para fazer trocas, é preciso que haja interação entre pessoas, e, na escola, o professor deve ser o principal mediador desse processo. $\mathrm{Na}$ sociedade informacional, o professor deixa de ser o detentor do conhecimento e passa a ser um elo importante no processo de ensino e de aprendizagem entre as tecnologias e seus alunos.

Para Lück (2006) e Ferretti (1995), é essencial ressignificar o modo de ensinar e aprender, para os autores, o professor deve deixar um pouco de lado o quadro, o giz e o livro didático para trabalhar de maneira mais cooperativa com os seus alunos, compartilhando informações e tornando suas aprendizagens mais atrativas e lúdicas.

Acredita-se que boa parte do corpo docente utiliza as TDR para não ser tarjada como 'desatualizada'. Ferretti (1995) acredita que é preciso explorar o campo educacional para gerar mudanças que não sejam apenas modismos, 'folclore pedagógico’ ou ainda simples expressões de modernidade que têm como finalidade inovar por inovar. A verdade é que poucos compreendem o porquê, o conteúdo, o diferencial para utilizar tais ferramentas, sendo fundamental pensar numa "inovação que não dá atenção ao acessório e à aparência, mas que aprofunda os aspectos importantes de uma nova formação compreensiva e integral” (SEBARROJA, 2001, p.18). Assim, percebe-se que o foco da inovação não está na ferramenta e sim no método, na prática e na motivação de cada professor. Devido a isto, acredita-se que as alunas-professoras do PEAD têm um diferencial, pois ao longo do curso elas passaram a acreditar na potencialidade das tecnologias e isso as auxiliou a pensar em novas perspectivas dentro dos seus espaços escolares. Embora ainda encontrem resistências e obstáculos para utilizar as TDR potencialmente no processo de ensino e de aprendizagem.

A partir da discussão de todos os pontos destacados acima, formulou-se uma definição que abrangesse as diferentes definições do conceito de Inovação Pedagógica embasada na leitura e análise de diferentes autores, como Fino (2008), Sebarroja (2001), Ferretti (1995) e Fullan (2009). Assim, ao longo da pesquisa amparou-se na ideia que o conceito de 'Inovação Pedagógica se insere numa perspectiva na qual as ações conjuntas da escola e dos professores se dão através da ruptura com uma situação vigente. O foco da inovação está na sua ação de mudança intencional, bem planejada, deliberada, criativa, crítica e conscientemente assumida na criação de situações de aprendizagens diferenciadas e novas para melhorar a prática educativa no contexto escolar'.

\section{Metodologia}

Para responder ao problema a ser pesquisado, que é descobrir 'De que forma professoras, que realizaram a formação num curso a distância mediado por tecnologias digitais de rede, utilizam-nas em sua prática educativa?', partiu-se da ideia que o PEAD incluiu digitalmente suas alunas e elas têm maior propriedade para fazer o uso das tecnologias de maneira inovadora.

No PEAD, as alunas são incentivadas a criarem materiais pedagógicos digitais para o trabalho com os seus alunos. Já é possível observar várias iniciativas de produção de materiais pedagógicos para aplicação com alunos dos Anos Iniciais do Ensino Fundamental. Essas iniciativas vêm mostrando que as alunas-professoras, ao vivenciarem o uso das tecnologias aliado às metodologias construtivistas, no âmbito do curso de formação, tendem a replicar essas formas de trabalho na sua prática docente (NEVADO et al, 2009, p.386). 
Este relato da equipe formadora do curso, no ano de 2009, leva a crer que a prática dessas alunas em sala de aula é crítica, criativa e reflexiva. Por isso, tendem a trazer novas práticas para suas salas de aula e estas se caracterizam novas ou inovadoras, levando em conta que o curso possibilitou a inclusão digital e o trabalho das tecnologias com viés pedagógico.

A coleta de dados da pesquisa ocorreu em duas etapas. Na primeira utilizaramse, como critérios, ter sido aluna do curso PEAD, ser unidocente, lecionar em uma escola pública de Porto Alegre e inserir as tecnologias digitais de rede em suas práticas educativas. A segunda consistiu na abordagem qualitativa através de estudo de casos das práticas educativas de três alunas-professoras através da análise de registros em arquivo, observação (durante sete dias consecutivos para cada aluna) e entrevista aberta ao longo das observações.

Ao tentar compreender de que forma um curso mediado pelas tecnologias pode transformar a prática docente nova ou inovadora, define-se a natureza da pesquisa como aplicada, pois, como defende Jung (2009), ela objetiva a aplicação de conhecimentos básicos, a fim de agregar resultados novos ao processo da pesquisa. Prodanov e Freitas (2009) defendem que essa natureza de pesquisa "procura produzir conhecimentos para aplicações práticas dirigidas a soluções de problemas específicos. Envolve verdades e interesses locais” (p.139). Nesse aspecto, tentou-se esclarecer se as TDR auxiliam na qualificação das práticas educativas inovadoras para que se possa repensar sobre as futuras formações de professores. Ou seja, pretende-se, através do estudo, investigar se o processo de formação que as alunas-professoras do PEAD passaram possibilitou que elas criassem inovações nas suas práticas educativas.

A pesquisa define-se descritiva, pois busca compreender o fenômeno inovação pedagógica através das práticas educativas das alunas-professoras. Jung (2009) e Prodanov e Freitas (2009) chamam a atenção para as seguintes características dessa pesquisa: "[...] ela descreve características de um fenômeno ou população, classifica, explica através de registros de 'como' funciona ou de 'como' foi feito e interpreta fatos ou variáveis que ocorrem sem interferência do pesquisador” (PRODANOV E FREITAS, 2009, p.63). A pesquisa descritiva é incluída na maioria das pesquisas nas áreas das humanas e sociais, especialmente aquelas preocupadas com a atuação prática.

No que se refere à abordagem do problema, esta pesquisa se caracteriza como qualitativa, por auxiliar na interpretação dos fenômenos e na atribuição de significados aos dados pesquisados. Para Prodanov e Freitas (2009, p.81), "O processo e o seu significado são os focos principais de abordagem”, pois é através do ambiente natural que o pesquisador, instrumento-chave, irá coletar os dados. Fino (2008) defende que a metodologia de investigação qualitativa é a mais adequada para compreender e descrever os fenômenos que ocorrem nas escolas. Nesse caso, os dados foram coletados nas salas de aula e laboratórios de informática, por meio da observação das práticas educativas das alunas-professoras.

A fim de contemplar os procedimentos técnicos e estratégias de pesquisa, realizou-se um estudo de casos. Robert Yin, desde sua primeira publicação em 1994, vem se tornando referência nesse assunto. O autor afirma que "Um estudo de caso é uma investigação empírica que investiga um fenômeno contemporâneo dentro de seu contexto da vida real, especialmente quando os limites entre o fenômeno e contexto não estão claramente definidos" (YIN, 2001, p.32). Devido a isso, destaca-se a riqueza desse tipo de procedimento para que, através de um olhar 'clínico' e 'moderado' sobre as práticas educativas das alunas-professoras, distinga-se a novidade da inovação. Diante dos critérios definidos pelo autor, esse método se justifica nesta pesquisa por contemplar os pontos descritos anteriormente. Primeiro por ser uma pesquisa que busca 
compreender como são as práticas educativas das alunas-professoras, "são inovadoras ou apresentam novidades”, além de investigar se suas formações no PEAD influenciaram em suas práticas educativas, possibilitando a criação de inovações na mediação das TDR.

Fundamentando-se em Yin (2001), a construção de uma pesquisa de estudo de caso, utilizaram-se os documentos: registros em arquivo com informações que auxiliaram a fornecer pistas sobre as ações que foram observadas e protocolos de observação que foram preenchidos durante a pesquisa em campo a fim de auxiliar na análise dos dados. Complementou-se a pesquisa com entrevistas abertas que auxiliaram a extrair fatos, opiniões e encontrar respostas às dúvidas por meio de insights que surgiram nas observações.

Para a realização da metodologia de pesquisa escolhida neste trabalho foi preciso uma aproximação de três sujeitos (alunas-professoras do curso PEAD) em suas escolas e cada caso foi trabalhado como único, o que define o método da pesquisa como estudo de casos.

Trabalhou-se com diferentes fontes de evidência para o desenvolvimento desta pesquisa, tomando como ponto de partida as características básicas propostas por Yin (2001, p. 197), “engajamento, instigação e sedução”, para conseguir criar uma cadeia de evidências que possibilitassem transmitir e ampliar o estudo realizado.

\section{Resultados e Discussões}

Este tópico auxiliará para que se faça um agrupamento das observações que foram realizadas durante a pesquisa. Cada professora pesquisada apresentou uma realidade muito diferenciada através da sua prática. Cada observação trouxe peculiaridades que enriqueceram a pesquisa e auxiliaram a compreender como são as práticas nas escolas e quais são as dificuldades para implementar inovações pedagógicas nas suas salas de aula.

Através das observações, foi possível perceber que, no entendimento das professoras, o trabalho com tecnologias está condicionado ao uso do computador. As demais TDR que aparecem em suas práticas não são entendidas claramente como inserção de tecnologia em suas salas de aulas. Para a 'segunda aluna-professora9', esta clareza é mais evidente já que ela leva para a sua sala de aula uma câmera digital, o notebook e o celular para trabalhar com seus alunos, sendo que estes equipamentos são de uso pessoal. Ao usar as tecnologias, ela intenciona a reflexão sobre as posturas dos alunos, além de estimular suas autocríticas a partir dos seus acertos e erros. Sebarroja (2001, p.83) acredita na “[...] importância da repetição orientada de determinadas tarefas, como o refazer e reescrever textos para que os alunos possam ir modificando erros anteriores e avançando na aprendizagem”. Para Piaget, o erro é essencial à (re)construção da aprendizagem e para compreensão do modo que os alunos enfrentam um problema. Conforme Becker e Marques (2001, p.61) “[...] se o erro puder fazer parte do processo - não como algo a ser castigado, mas como uma tentativa de encontrar uma resposta, que tem uma lógica em si - a curiosidade, a iniciativa e o desejo de encontrar respostas podem ser sentidos como positivos”. A 'segunda aluna-professora' também trazia as tecnologias como materiais complementares à sua prática em sala de aula.

Através dos relatos da 'terceira aluna-professora', percebeu-se que ela não identifica outras tecnologias além do computador para ser utilizado em sala de aula. A 'primeira aluna-professora' utiliza com mais frequência o laboratório de informática e quanto às demais tecnologias que ela insere na sua prática, como o celular, não parecem ser identificadas por ela como uma tecnologia que pode ser abordada com viés educativo e explorada para interagir com os alunos. Fundamentando-se na teoria de Jean 
Piaget, Becker (2010) afirma que é na interação entre sujeito e meio que se constrói o conhecimento: "Interacionismo significa que o conhecimento não acontece pela formação ou atuação do sujeito apenas; nem por pressão do meio externo [...]. Acontece por interação entre o sujeito, com sua extraordinária complexidade, e esse meio, com toda sua complexidade” (2010, p.15). O autor acredita que o verbo interagir deve ser sempre conjugado no plural, pois a interação só ocorre quando há ação de mais de um polo, entre o sujeito e o meio físico ou social, neste caso entre a professora e os alunos.

As três escolas pesquisadas apresentaram problemas técnicos com relação à internet em seus laboratórios de informática, e isso remete ao pouco investimento em tecnologias para a modernização das salas de aulas. Na escola da 'primeira alunaprofessora', o laboratório de informática é utilizado com o auxílio de uma professora responsável pelo local, mas em alguns momentos a conexão fica instável e prejudica a continuidade dos projetos que estão sendo desenvolvidos já que ela tem apenas um horário a cada quinze dias no laboratório. Sancho (2006) afirma que, para se trabalhar com as tecnologias nas escolas é essencial uma boa conexão de internet, e "Isto significa importante investimento econômico" (p.27), o que, segundo a autora, em países em desenvolvimento, pode ser um problema tanto para a inserção de tecnologias educacionais, como para a inovação pedagógica na escola.

Na escola da 'segunda aluna-professora', o laboratório não é utilizado por nenhuma professora, já que elas alegam não haver nenhuma pessoa responsável para dar manutenção ao local e para auxiliar no acesso dos alunos. Rudduck, Chapalin e Wallace (1996 apud FULLAN, 2009, p.164-165) constataram que, quanto mais os alunos se envolvem com sua aprendizagem, maiores são os resultados positivos sobre a sua formação integral como sujeito, ou seja, maior sua autoestima, persistência, envolvimento, facilidade na realização das atividades relacionadas à sala de aula, são menos ansiosos e estabelecem relacionamentos agradáveis com seus colegas e professores. Sendo assim, acredita-se na importância do aluno construir sua própria aprendizagem, pois o processo de ligar e desligar o computador deveria também ser explorado no ato de ensinar. Para se pensar na formação integral e para o futuro do aluno é preciso compreender que essas são habilidades que deveriam ser valorizadas nos seus processos de aprendizagem.

A escola da 'terceira aluna-professora' tem dois laboratórios, mas ambos vêm sendo pouco utilizados devido a não terem acesso à internet e os computadores serem configurados com o sistema Linux, que as professoras da escola não dominam e a escola também não contar com nenhum profissional destinado para manter este local. Das três escolas, apenas o da 'terceira aluna-professora' não dispõe de rede wifi.

Percebe-se que o domínio das tecnologias das três professoras se embasa nos conhecimentos adquiridos durante suas formações em um curso a distância, pois elas relatam que em algum momento das suas práticas educativas fizeram o uso do pbworks e/ou blog, ferramentas que trabalharam constantemente ao longo das suas formações. Fullan (2009) acredita que investir na formação docente propicia a mudança dos seus comportamentos, e estes mudam antes mesmo das crenças, o que é comprovado através dos estudos realizados por Pteffer e Sutton (2000, apud FULLAN, 2009, p.63), “capacitação primeiro, e julgamento depois - pois é isso que motivará mais pessoas”. Aprender dia-a-dia é um forte motivador para mudança da prática educativa.

As experiências de capacitação desenvolvem as habilidades, a clareza (quando você se torna mais capacitado, você se torna mais claro) e a motivação. Com elas são geradas coletivamente, ou seja, compartilhadas pelo grupo, elas se tornam novas forças para a melhora (FULLAN, 2009, p.64-65). Isso demonstra o quanto a capacitação é fundamental para motivar os professores a conhecerem novos recursos para inserir em 
suas salas de aula e para investirem, cada vez mais, em suas formações. Segundo o autor, os resultados positivos são motivadores, o que faz com que os professores ousem experimentar progressivamente a cada sucesso conquistado, caso contrário é fundamental não se desmotivar.

Embora a prática educativa das professoras não possa ainda ser categorizada como inovadora, percebe-se que todas elas acreditam no potencial das tecnologias e que valorizam os seus usos em suas práticas. Mesmo a 'terceira aluna-professora', que não as vem utilizando, relata que o que mais sente falta no uso das tecnologias são os trabalhos cooperativos que os alunos realizavam. O trabalho cooperativo entre os alunos é fundamental na promoção do respeito entre os pares para enriquecer a aprendizagem de todos. Segundo Jean Piaget, o sujeito:

[...] torna-se capaz de cooperar, porque não confunde mais seu próprio ponto de vista com o dos outros, dissociando-os mesmo para coordená-los. Isso é visível na linguagem entre as crianças. As discussões tornam-se possíveis, porque comportam compreensão a respeito dos pontos de vista do adversário e procura de justificações ou provas para a afirmação própria. As explicações mútuas entre crianças se desenvolvem no plano do pensamento e não somente no da ação material (1986, p.43).

Esses são alguns dos valores que as professoras destacaram como fundamental no trabalho com as tecnologias. Pode-se definir que a prática das professoras pesquisadas têm muitos valores além dos descritos neste artigo, que demonstraram suas dedicações com seus fazeres pedagógicos.

\section{Conclusão}

O estudo sobre o conceito de Inovação Pedagógica surgiu ao tentar compreender o que de novo vem ocorrendo na área educacional no trabalho mediado pelas tecnologias nas práticas educativas em meio à sociedade informacional. Ou seja, como professores e alunos estão enfrentando os novos desafios que se postam na sala de aula para ensinar e aprender, assim como as demandas da comunidade escolar e as necessidades para formações futuras. Na trajetória deste estudo, percebeu-se que a compreensão do conceito de inovação pedagógica é de grande relevância quando compreendido como uma ruptura de paradigmas na prática educativa, mas que, para que essa ocorra, há diversos fatores envolvidos, o que, de certa forma, torna o seu processo complexo.

As transformações das gerações de alunos com habilidades potencializadas pelo uso das tecnologias desafia o professor na sua prática educativa diária. É preciso estar disposto a romper paradigmas e compreender os desafios e limites determinados por uma realidade social diferenciada. Nesta nova perspectiva, o professor e o gestor são os principais protagonistas da mudança no espaço escolar. Paulo Freire fomenta a ideia de que o tempo demanda mudanças, possibilidades e não determinismo, "significa que somos seres condicionados, mas não determinados. Reconhecer que a História é tempo de possibilidade e não de determinismo, que o futuro, permita-se-me reiterar, é problemático e não inexorável” (FREIRE, 2009, p.21). O autor expressa a importância de reconhecer aprendizagens diferenciadas e não temer novas experiências.

Diante dessa argumentação, acredita-se na necessidade de investir na capacitação de professores e contribuir com debates abertos entre as comunidades educacionais, juntamente aos alunos e corpo docente para que se pense em uma escola para o século XXI e para o futuro da formação de professores. 
A intenção deste estudo não é a de afirmar que há uma maneira correta para praticar uma pedagogia inovadora, pois, como afirma Sebarroja (2001, p.80), "nem todos os métodos são válidos ou igualmente válidos; ainda que convenha estarem abertos à diversidade, combinação e experimentação de várias metodologias tratando sempre de adaptá-las ao contexto socioeducativo da escola”. Acredita-se, portanto, na ação livre à criação crítica e consciente das práticas educativas juntamente à escola e à comunidade. Fullan (2009) reafirma a citação anteriormente mencionada de Sebarroja (2001), ao defender que “A ideia é ser um consumidor crítico de ideias externas, enquanto se trabalha a partir de uma base para entender e alterar o contexto local. Não existe nenhuma resposta completa 'por aí'” (p.119). Devido a isto, é preciso que o professor esteja disposto a buscar alternativas que enriqueçam suas práticas educativas.

Para isto, é preciso acreditar, ter fé, se motivar, pois, para Fullan (2009), "Mesmo as melhores ideias técnicas, na ausência de paixão e comprometimento, não vão muito longe” (p.102). Nessa perspectiva, a motivação provoca energia para implementar novos processos de mudança. Assim, acredita-se que a motivação da comunidade escolar, e, especialmente, dos professores permitem a abertura das portas das salas de aula para que mudanças qualitativas e consistentes sejam colocadas em prática.

A cada escola visitada, novos elementos surgiam e das três professoras pesquisadas nenhuma apresentava situação igual a da outra, o que demonstra que a prática é múltipla e que deve ser adaptada conforme as necessidades de cada turma e de acordo com a estrutura de sua escola. Durante a pesquisa, reconheceu-se a importância do PEAD na formação das professoras, pois o curso contribuiu para que as alunas alterassem suas crenças e mesmo em pequena escala nas abordagens de ensino que dão ao uso de novos materiais. A capacitação constante deve estar relacionada a novas crenças que façam com que o professor altere sua prática com consciência e sabedoria.

As escolas ainda têm muito para mudar e sabe-se que "A mudança não será realizada da noite para o dia, mas também não pode ser de tempo ilimitado" (FULLAN, 2009, p.47). Assim, diante da complexidade dessa temática, o autor faz um comparativo entre sua teoria desde o ano de 1993 e relata que ainda considera que a formação docente é ao mesmo tempo "[...] o pior problema e a melhor solução em educação" (FULLAN, 2009, p.249). O autor reconhece que a capacitação dos professores é fundamental, mas que a defasagem da profissão se deve pela sobrecarga da sua profissão.

Essas questões foram pesquisadas através da metodologia da pesquisa que propunha um estudo de casos para compreender a pergunta 'De que forma professoras, que realizaram a formação num curso a distância mediado por tecnologias digitais de rede, utilizam-nas em sua prática educativa?'. Pode-se dizer que as professoras pesquisadas dominam as tecnologias, especialmente as utilizadas durante o curso de formação, mas, quando se trata de inovar através das tecnologias, ainda apresentam dificuldades, sendo assim, acredita-se que a formação num curso a distância mediado pelas tecnologias foi um incentivador na inserção de tecnologias em suas salas de aula, mas não determinante para inovarem. Assim, pode-se dizer que o objetivo geral desta pesquisa, 'Investigar se o modo como as alunas-professoras egressas da Pedagogia a distância da Universidade Federal do Rio Grande do Sul estão utilizando as tecnologias digitais de rede caracteriza-se como inovação pedagógica em suas práticas educativas', foi atingido e observada a presença parcial das TDR como inovação pedagógica em algumas práticas. No que se refere ao primeiro objetivo específico, 'Analisar se as práticas educativas das alunas-professoras egressas do PEAD são inovadoras', percebeu-se que a maioria das práticas são novas, mas não inovadoras. As professoras 
utilizam a tecnologia, mas não alteraram a metodologia do seu uso, não há uma mudança intencional de tornar a prática educativa mais atrativa e inovadora. Ou seja, duas das três professoras usam tecnologias, para que os alunos realizem pesquisa em sites e para filmá-los, o que pode ser muito interessante no contexto escolar, mas não se caracteriza como algo inovador. Quanto ao segundo objetivo específico, 'Identificar se as tecnologias digitais de rede qualificam as práticas educativas das alunas-professoras egressas do PEAD', pode-se afirmar que as TDR trazem novidades, mas, apesar de não trazerem inovações, elas qualificam parcialmente a prática das professoras na medida em que elas utilizam as tecnologias para apoiar o conteúdo trabalhado em sala de aula, embora o uso da tecnologia ainda esteja muito focado nas ações das professoras e não na dos alunos. Isso é comprovado quando as professoras manuseiam as tecnologias para produzir o material que posteriormente será 'assistido' pelo aluno, ou quando a professora abre as páginas da internet para navegação dos mesmos. Com relação ao terceiro e último objetivo específico, 'Verificar se existem outros fatores intervenientes na comunidade escolar, que fomentem ou dificultem a implementação de práticas educativas inovadoras na escola', foi observado constantemente nas escolas que tais fatores estão presentes nas práticas das professoras observadas. Podem ser citadas a falta de manutenção das máquinas, a ausência de um profissional que auxilie no laboratório de informática, a restrição na carga horária para utilização dos laboratórios, a dificuldade de conexão com a internet e a resistência da direção e pais.

Sabe-se que há alguns pontos que limitaram este estudo, e um dos fatores foi o restrito número de sujeitos que se dispuseram a ser observados. Isso se deve, também, por haver diversos professores licenciados pelo PEAD que foram alocados para outras áreas das escolas pela capacitação e domínio das tecnologias.

Destaca-se aqui, portanto, a importância da prática educativa estar voltada para as transformações da era informacional e da compreensão do perfil do novo aluno que se posta nas salas de aula. Ao aceitar aprender, conhecer e se capacitar, a fim de inserir inovações em sua sala de aula, o professor se propõe a refletir sobre suas ações. Logo, é preciso estar atento às tendências e às mudanças que fazem parte da busca do aprimoramento profissional para que as tecnologias sejam aliadas na criação de inovações pedagógicas.

Nesse sentido, a pesquisa nos auxiliou a compreender as dificuldades encontradas pelas professoras, no que se refere às precariedades das escolas e do sistema em geral que faz a proibição de algumas TDR específicas, assim como celular. A estrutura de alguns laboratórios também dificulta o trabalho das professoras pois, embora elas demonstrem acreditar no diferencial das tecnologias quando inseridas na sala de aula, têm dificuldade em inovar suas práticas educativas.

Acredita-se que esta temática está em constante mudança, pois o estudo visa a contribuir com a sociedade, em especial, com os profissionais da área educacional, a fim de instigar a reflexão sobre o modo como as TDR estão sendo inseridas nos espaços escolares. A cada dia que passa, fala-se em novas tecnologias que estão sendo distribuídas nas salas de aulas, mas o momento é parar para pensar como que elas serão implementadas. Percebe-se a importância da capacitação dos professores para que se tente atingir o conceito construído e idealizado durante esta pesquisa, com o auxílio dos autores utilizados. Através do conceito, compreende-se que a 'Inovação Pedagógica se insere numa perspectiva na qual as ações conjuntas da escola e dos professores se dão através da ruptura com uma situação vigente. O foco da inovação está na sua ação de mudança intencional, bem planejada, deliberada, criativa, crítica e conscientemente assumida na criação de situações de aprendizagens diferenciadas e novas para melhorar 
a prática educativa no contexto escolar'. E é isto que se espera dos profissionais que utilizam as tecnologias para mediar suas práticas educativas.

\footnotetext{
${ }^{1}$ Quando adotado o termo 'alunas-professoras', deve-se entender que estas alunas são egressas do curso PEAD. Utilizou-se esta terminologia devido ao gênero feminino prevalecer entre as alunas. Durante a formação eram professoras em exercício.

${ }^{2}$ Trata-se de tecnologias conectadas na rede, o que facilita a troca e o acesso às informações. Entende-se por TDR: laptop, netbook, notebook, desktop, tablet e celulares.

${ }^{3}$ Castells utiliza este termo desde 1999 para exprimir a ideia de uma sociedade conectada em rede na era da informação.

4 "Redes são estruturas abertas capazes de expandir de forma ilimitada, integrando novos nós desde que consigam comunicar-se dentro da rede” (CASTELLS, 2001, p.498).

${ }^{5}$ Criado em 03/2008 é um organismo da União Europeia que tem, como missão, aumentar o crescimento sustentável e a competitividade na Europa, para reforçar sua capacidade de inovação.

${ }^{6}$ Termo mediação será utilizado para dar sentido à inserção das tecnologias digitais de rede no espaço escolar.

7 "[...] referring both to wisdom arising from the use of digital technology to access cognitive power beyond our innate capacity and to wisdom in the prudent use of technology to enhance our capabilities" (PRENSKY, 2009, p.1).

${ }^{8}$ Optou-se por manter a grafia no português de Portugal, por não haver interferência na sua compreensão.

${ }^{9}$ Serão dados os nomes para as alunas pesquisadas, conforme a ordem das observações, ou seja, 'segunda aluna-professora' equivale à segunda professora observada durante a pesquisa.
}

\section{Referências Bibliográficas}

BECKER, Fernando; MARQUES, Tania B. I. Aprendizagem humana: processo de construção. Pátio. Revista Pedagógica (Porto Alegre), Porto Alegre, v. IV, nº15, p. 58-61, 2001.

BECKER, Fernando. Ensino e Pesquisa: qual a relação? in BECKER, Fernando; MARQUES, Tânia B. I. (Org.). Ser professor é ser pesquisador. Porto Alegre: Mediação, 2010.

CAMPOS, Fernanda C. A. (org.) et al. Cooperação e Aprendizagem on-line. Rio de Janeiro: DP\&A, 2003.

CASTELLS, Manuel. A Sociedade em Rede. São Paulo: Paz e Terra, 2001.

FERRETTI, Celso João. A inovação na perspectiva pedagógica in GARCIA, Walter E. (coord.) Inovação Educacional no Brasil: Problemas e Perspectivas. Campinas: Autores Associados, 1995.

FINO, Carlos N. Inovação Pedagógica: significado e campo (de investigação) in FREIRE, Paulo. Pedagogia da autonomia: saberes necessários à prática educativa. $40^{\circ}$ ed. São Paulo: Paz e Terra, 2009.

FULLAN, Michael. O significado da Mudança Educacional. Porto Alegre: Artmed, 2009. GIGET, Marc. A Inovação só tem sentido se provocar satisfação nas pessoas. Gazeta do Povo, Paraná, $17 \quad$ ago. 2008.2 Disponível em: $<$ http://www.gazetadopovo.com.br/economia/conteudo.phtml?tl=1\&id=798646\&tit=Ainovacao-so-tem-sentido-se-provocar-satisfacao-nas-pessoas>. Acesso em: 12 mar. 2013.

HOWE, N.; STRAUSS, W. Millennials Rising: The Next Generations. New York: Vintage Books, 2000.

JUNG, Carlos F. Metodologia Científica e Tecnológica, 2009. Disponível em: $<$ http://www.pdfdownload.org/pdf2html/view_online.php?url=http\%3A\%2F\%2Fwww.dsce.fee. unicamp.br\%2F antenor\%2Fmod7.pdf> Acesso em: 10 abr. 2013. 
LÜCK, Esther H.. Inovações Pedagógicas: elementos para uma ressignificação de conceitos e práticas na gestão do ensino de graduação. VI Colóquio Internacional sobre Gestão Universitária na América Latina - INPEAU/UFSC: Blumenau, 2006.

MALAGGI, Vitor. Imbricando Projetos de Ensino-Aprendizagem e Tecnologias Digitais de Rede: busca da re-significações e potencialidades. Dissertação (Mestrado em Educação) Programa de Pós-Graduação em Educação, Faculdade de Educação, Universidade de Passo Fundo, UPF, Passo Fundo, 2009.

MORAES, Maria C. O Paradigma Educacional Emergente: implicações na Formação do Professor e nas Práticas Pedagógicas in Em aberto. Brasília, ano 16. No 70, 57-69p.; abr./jun. 1996.

NEVADO, Rosane et al. Inovações na Formação de Professores na Modalidade a Distância in Educação Temática Digital, Campinas, v.10, n.2, p.373-393, jun. 2009. Disponível em: $<$ http://www.pead.faced.ufrgs.br/sites/publico/pead-informacoes/ETD-2009-517.pdf $>$. Acesso em: 26 mar. 2013.

PIAGET, Jean. Seis estudos de psicologia. Rio de Janeiro: Forense, 1986.

PRODANOV, Cleber; FREITAS, Ernani C. Metodologia do Trabalho Científico: Métodos e técnicas da pesquisa e do trabalho acadêmico. Nova Hamburgo: Feevale, 2009.

PRENSKY, Marc. Nativos Digitais, Imigrantes Digitais, 2001. Disponível em: < http://crisgorete.pbworks.com/w/file/fetch/58325978/Nativos.pdf >. Tradução de Roberta de Moraes Jesus de Souza do Documento de Marc Prensky. On the Horizon (NCB University Press, Vol. 9 No. 5, October 2001). Acesso em: 16 mar. 2013.

PRENSKY, Marc. H. Sapiens Digital: From Digital Immigrants and Digital Natives to Digital Wisdom, 2009.2 Disponível em: $<$ http://www.innovateonline.info/pdf/vol5_issue3/h._sapiens_digital-

_from_digital_immigrants_and_digital_natives_to_digital_wisdom.pdf $>$. Acesso em: 17 abr. 2013.

SANCHO, Juana M.. De tecnologias da informação e comunicação a recursos educativos in SANCHO, Juana M. et al. Tecnologias para transformar a educação. Porto Alegre: Artmed, 2006.

SEBARROJA, Jaume C. A aventura de Inovar: a mudança na escola. Porto Alegre: Porto Editora, 2001.

TAPSCOTT, Don. Geração digital - a crescente e irreversível ascensão da Geração Net. São Paulo: Makron Books, 1999.

TEIXEIRA, Adriano C. Formação Docente e Inclusão Digital: a análise do processo de emersão tecnológica de professores. Tese (Doutora- do em Informática na Educação) Universidade de Federal do Rio Grande do Sul, Porto Alegre, 2005.

VEEN, Win; VRAKKING, Ben. Homo Zappiens: educando na era digital. Porto Alegre: Artmed, 2009.

YIN, Robert K. Estudo de caso: Planejamento e Métodos. $2^{\circ}$ ed. São Paulo: Bookman, 2001. 